\title{
New Approach For Simvastatin As An Antibacterial: Synergistic Effect With Bio-Synthesized Silver Nanoparticles Against Multidrug-Resistant Bacteria
}

This article was published in the following Dove Press journal: International Journal of Nanomedicine

\author{
EP Figueiredo' \\ JM Ribeiro' \\ EK Nishio' \\ S Scandorieiro' \\ AF Costa ${ }^{2}$ \\ VF Cardozo' \\ AG Oliveira' \\ N Durán ${ }^{2-4}$ \\ LA Panagio' \\ RKT Kobayashi ${ }^{\prime}{ }^{\prime}$ \\ G Nakazato (D) \\ 'Department of Microbiology, Center of \\ Biological Sciences, Universidade Estadual \\ de Londrina, Londrina, Paraná, Brazil; \\ ${ }^{2}$ NanoBioss, Institute of Chemistry, \\ Universidade Estadual de Campinas, \\ Campinas, São Paulo, Brazil; ${ }^{3}$ Institute of \\ Chemistry, Universidade Estadual de \\ Campinas, Campinas, São Paulo, Brazil; \\ ${ }^{4}$ LNNano (National Laboratory of \\ Nanotecnology), CNPEM, Campinas, São \\ Paulo, Brazil
}

Background: Multidrug-resistant bacteria such as extended-spectrum beta-lactamase (ESBL), Enterobacteriaceae, and methicillin-resistant Staphylococcus aureus (MRSA) pose a challenge to the human health care system. MRSA is among the major causes of hospitalacquired and community infections.

Methods: Therefore, in the present study, we evaluated the antibacterial activity of silver nanoparticles synthesized by Fusarium oxysporum $\left(\mathrm{AgNP}_{\text {bio }}\right)$ in combination with simvastatin against reference and multidrug-resistant bacterial strains.

Results: Simvastatin showed a minimal inhibitory concentration (MIC) ranging from 0.062 to $0.25 \mathrm{mg} \mathrm{mL}^{-1}$ against MRSA. AgNP bio with a size of $77.68 \pm 33.95 \mathrm{~nm}$ and zeta potential $-34.6 \pm 12.7 \mathrm{mV}$ showed an MIC of $0.212 \mathrm{mg} \mathrm{mL}^{-1}$ against $S$. aureus including MRSA strains. The checkerboard assay and time-kill curves exhibited a synergistic effect of the simvastatin- $\mathrm{AgNP}_{\text {bio }}$ combination on antibacterial activity against MRSA strains. The combination of simvastatin and $\mathrm{AgNP}_{\text {bio }}$ demonstrated antibacterial activity against Escherichia coli producing ESBL. Scanning electron microscopy showed the formation of cell surface protrusions after treatment with $\mathrm{AgNP}_{\text {bio }}$ and the formation of a large amorphous mass after treatment with simvastatin, both in MRSA.

Conclusion: Our results indicate that the combination of $\mathrm{AgNP}_{\text {bio }}$ and simvastatin could be a great future alternative in the control of bacterial infections, where, when combined with simvastatin, smaller doses of $\mathrm{AgNP}_{\text {bio }}$ are required, with the same antibacterial activity.

Keywords: antibacterial, metallic nanoparticles, multidrug-resistant bacterial, statins, synergism

\section{Introduction}

Antibiotics are the most commonly prescribed drugs in hospitals. This intensive and frequent use favors the selection of resistant strains, which can cause serious infections in patients. Resistance leads to ineffective clinical treatment in the case of some bacterial species, increasing the problem of microbial resistance to antimicrobials. ${ }^{1}$ Resistance such as extended-spectrum $\beta$-lactamase producing (ESBL), Klebsiella pneumoniae carbapenemase (KPC) producing, and methicillin-resistant Staphylococcus aureus (MRSA) lead to therapeutic failure, high treatment cost, and patient death (high mortality). ${ }^{2,3}$ MRSA strains were the most prevalent pathogens, contributed to $56 \%$ of nosocomial and community infections, and were the most common multidrug-resistant microorganisms in hospitals. ${ }^{4}$ A study published in 2016 estimated a rate of 10 million deaths due
Correspondence: G Nakazato

Department of Microbiology, Center of Biological Sciences, Universidade Estadua de Londrina, Campus Universitário, CEP, Londrina 86055-990, Paraná, Brazil

Tel +5543337 I 4396

Fax +55 43 3371 4788

Email gersonakazato@yahoo.com.br 
to antimicrobial-resistant microorganisms in $2050 .{ }^{1}$ Therefore, there is a necessity to discover new treatment options.

Statins are known for their antihyperlipidemic effects by competitively inhibiting the enzyme HMG-CoA reductase, decreasing cholesterol biosynthesis. ${ }^{5}$ This drug is also known to present pleiotropic effects, such as anti-inflammatory and antithrombotic. $^{6,7}$ Furthermore, in 2008 a study that described the antibacterial effects of statins found that simvastatin and fluvastatin were active against MRSA and Vancomycin-resistant Enterococcus (VRE) strains. ${ }^{8}$

Metals have been used since ancient times as antibacterial agents and present different properties and spectra of action. Among the metals, silver is one of the most commonly used due to its efficiency as an antimicrobial and low toxicity, being impregnated in utensils and materials used in medicine. ${ }^{9}$

With the advent of nanotechnology in the medical area, silver nanoparticles (AgNP) have become widely studied for their antimicrobial action, including against multidrug-resistant bacteria. ${ }^{10-15}$ AgNP are interesting when compared to silver ions due to their small size and high superficial area, which, in turn, improves their ability to react with multiple molecules. This feature leads to an ultra-large surface area per volume, where a large proportion of atoms are in immediate contact with the environment and readily available for reactions. ${ }^{16-20}$ Biological synthesis is interesting when compared with chemical and physical syntheses because it not uses toxic solvents, being an environmentally friendly technology and low-cost. ${ }^{21,22}$ Therefore, metallic nanoparticles produced by biogenic synthesis with biomolecules and proteins hold up the stabilization of nanosystems. ${ }^{21,23,24}$

Despite the well-known antibacterial activity of silver, silver-resistant Escherichia coli was isolated and identified from a burn wound treated with silver nitrate. ${ }^{25}$ In addition, resistant microorganisms were isolated from different environments with a natural occurrence of silver, such as in mines and marine water, ${ }^{19,26,27}$ and, a recent study showed how fast $E$. coli develops resistance after contact with AgNP for several generations. ${ }^{28}$

To avoid this problem, according to the literature, combining $\mathrm{AgNP}_{\text {bio }}$ with other antibiotic compounds is a promising new strategy to control resistant bacterial infections, since it is effective against multidrug-resistant bacteria and the combination decreases the emergence of new antimicrobial resistance. $^{12,14,29}$

The combination of nanoparticles with antibiotics could have great potential in the control of multidrug-resistant microorganisms. This combination results in an improved bactericidal effect compared to drugs alone. ${ }^{20}$ AgNP has demonstrated different antimicrobial interactions depending on the microorganism strain and compound tested. ${ }^{30}$ Ampicillin, kanamycin, chloramphenicol, and erythromycin showed increased antibacterial activity when combined with AgNP against Gram-positive and Gram-negative bacteria. ${ }^{29}$ The combination of amoxicillin and AgNP resulted in a synergistic effect against E. coli. ${ }^{18}$ Phenazine-1-carboxamide combined with silver nanoparticles synthetized by Fusarium oxysporum $\left(\mathrm{AgNP}_{\mathrm{bio}}\right)$ resulted in a synergistic effect against MRSA. ${ }^{12}$ Eugenol with AgNP ${ }_{\text {bio }}$ showed a synergistic effect against Streptococcus agalactiae. ${ }^{31}$ AgNP in combination with cinnamaldehyde exhibited a synergistic effect against spore-forming bacterial strains. ${ }^{32}$ A recent study demonstrated the antibacterial activity of oregano essential oil combined with $\mathrm{AgNP}_{\text {bio }}$. These combinations demonstrate antibacterial activity against multidrug-resistant bacteria. ${ }^{14}$ Besides, a recent report showed antifungal activity of simvastatin combined with $\mathrm{AgNP}_{\text {bio }}$ against toxigenic species of Aspergillus. ${ }^{33}$

In the present study, we evaluated, for the first time, the antibacterial activity of simvastatin combined with $\mathrm{AgNP}_{\text {bio }}$ against reference and multidrug-resistant bacterial strains and analyzed the bacterial morphological alterations through electronic microscopy. This combination is under patent BR1020140323759 (INPI - Brazil).

\section{Materials And Methods}

\section{Simvastatin}

Simvastatin was obtained commercially (Henan Topfond Pharmaceutical Co. Ltd, China) and dissolved in dimethyl sulfoxide (DMSO) $100 \% \mathrm{vv}^{-1}$ at a stock concentration of $5 \mathrm{mg} \mathrm{mL}^{-1}$.

\section{Synthesis Of The Silver Nanoparticles}

$\mathrm{AgNP}_{\text {bio }}$ was obtained biologically by fungus-mediated synthesis as previously described. ${ }^{34}$ This methodology of $\mathrm{AgNP}_{\text {bio }}$ production has been patented (Patent, 2006, PI 0605681-4A2). The F. oxysporum strain 551 used was obtained from the culture collection of the Molecular Genetics Laboratory ESALQ-USP, Piracicaba-SP, Brazil. We cultured F. oxysporum in malt agar $\left(\right.$ Difco $\left.^{\circledR}\right)$ containing $0.5 \%$ yeast extract, $2 \%$ malt extract, $2 \%$ agar, and distilled water for 7 days at $28^{\circ} \mathrm{C}$. We then added $10 \mathrm{~g}$ of fungal biomass (previously washed) from the culture medium to $100 \mathrm{~mL}$ of sterile distilled water and incubated for 
$72 \mathrm{hrs}$ at $28^{\circ} \mathrm{C}$. Subsequently, the supernatant was separated from the fungal biomass by vacuum filtration and $\mathrm{AgNO}_{3}\left(\right.$ Sigma-Aldrich $\left.{ }^{\circledR}\right)$ was added to the supernatant to a final concentration of $10 \mathrm{mM}$; the system solution was kept incubated at $28^{\circ} \mathrm{C}$ in the absence of light until formation of $\mathrm{AgNP}_{\text {bio. }}$ Observation of $\mathrm{AgNP}_{\text {bio }}$ formation was performed visually and by absorptions until the formation of nanoparticles. We measured absorptions using ultraviolet-visible spectrophotometry (Varian Cary 50 Probe) to verify the formation of silver nanoparticles that presented surface plasmon resonance at $420 \mathrm{~nm}$. After purification, the $\mathrm{AgNP}_{\text {bio }}$ was characterized.

\section{Characterization of The $\mathrm{AgNP}_{\text {bio }}$ And Simvastatin}

Morphological and size of $\mathrm{AgNP}_{\text {bio }}$ was determined by photon correlation spectroscopy using ZetaSizer NanoZS $\left(\right.$ Malvern $^{\circledR}$ ), the same instrument was used to perform the zeta potential measurement and polydispersity index (PDI). Transmission Electron Microscopy (TEM) was performed to confirm morphological and size of $\mathrm{AgNP}_{\text {bio. }}$ UV-vis was made to detect wavelength corresponding to $\mathrm{AgNP}_{\text {bio. }}$. Size of simvastatin particles was analyzed using Dynamic Light Scattering (DLS).

\section{Bacterial Strains}

Two reference methicillin-sensitive St. aureus (MSSA) strains (ATCC 25923 and ATCC 29213), two reference MRSA strains (MRSA N315 and MRSA BEC 9393), E. coli ATCC 25922, and extended-spectrum beta-lactamases E. coli-producing (ESBL 176) were used in this study. MRSA N315 strain was provided by Dr. Elsa Masae Mamizuka (Universidade de São Paulo, São Paulo-SP, Brazil) and BEC 9393 strain by Dr. Agnes Marie Sá Figueiredo (Universidade Federal do Rio de Janeiro, Rio de Janeiro-RJ, Brazil). E. coli ESBL 176 strain was provided by Dra. Eliana Carolina Vespero (University Hospital - HU, Universidade Estadual de Londrina, Londrina-PR, Brazil). Bacterial strains were stored in brain heart infusion (BHI) broth containing 20\% $\left(\mathrm{vv}^{-1}\right)$ glycerol and maintained at $-80^{\circ} \mathrm{C}$.

\section{Antimicrobial Disk Susceptibility Test - Disk Diffusion}

We performed the antimicrobial disk susceptibility test according to previously described procedures. ${ }^{35}$ Previously grown bacteria were suspended in saline according to 0.5
McFarland turbidity (corresponding to approximately $1 \mathrm{x}$ $10^{8} \mathrm{CFU} \mathrm{mL}^{-1}$ ) and the bacterial suspension was inoculated on a plate with Muller-Hinton agar (MHA) using a cotton swab according to the Clinical and Laboratory Standards Institute. $^{36}$ The disks containing $10 \mu \mathrm{L}$ of simvastatin and $\mathrm{AgNP}_{\text {bio }}$ (corresponding to $0.115 \mathrm{mg}$ and $169.86 \mathrm{mg}$, respectively) were placed on the surface of an inoculated agar plate. A negative control of DMSO was added to the test. The plates were incubated for $24 \mathrm{hrs}$ at $37^{\circ} \mathrm{C}$ and the growth inhibition halo was measured. ${ }^{35}$

\section{Minimal Inhibitory Concentration Of Simvastatin And $\mathrm{AgNP}_{\text {bio }}$}

We determined minimal inhibitory concentration (MIC) by broth microdilution assay in 96-well microplates (Corning $^{\circledR}$ ) according to the Clinical and Laboratory Standards Institute guidance. ${ }^{37}$ In brief, we added different concentrations of simvastatin (from $0.015 \mathrm{mg} \mathrm{mL}^{-1}$ to $0.250 \mathrm{mg} \mathrm{mL}^{-1}$ ) and $\mathrm{AgNP}_{\text {bio }}$ (from $0.013 \mathrm{mg} \mathrm{mL}^{-1}$ to $0.212 \mathrm{mg} \mathrm{mL}^{-1}$ ) diluted in Mueller-Hinton broth (MHB). Bacteria were grown in MHA medium and suspended according to $0.5 \mathrm{McF}$ arland as previously described. This bacterial suspension was diluted in MHB to a ratio of 1:100 and inoculated in 96-well microplates at a density of $5.0 \times 10^{5} \mathrm{CFU} \mathrm{\textrm {mL } ^ { - 1 }}$ per well. We added DMSO as a negative control at equal concentrations $\left(1.25\right.$ to $\left.5 \% \mathrm{vv}^{-1}\right)$ to those used to dilute simvastatin. MHB medium was used for sterility control, and the positive control was performed by adding MHB medium and bacteria. The microplates were incubated at $37^{\circ} \mathrm{C}$ for $24 \mathrm{hrs}$. MIC was read visually and defined as the minimal concentration that inhibits bacterial growth visually according to turbidity. The assay was performed in triplicate.

\section{Antibacterial Combination Assay (Checkerboard)}

After determining MIC of isolated compounds, we tested two compounds ( $\mathrm{AgNP}_{\text {bio }}$ and simvastatin) together to evaluate the antibacterial interaction between them. The checkerboard assay was performed in 96-well microplates, ${ }^{38}$ where both compounds were diluted in MHB in combination, with concentrations ranging from 0.015 .6 to $0.125 \mathrm{mg} \mathrm{mL}^{-1}$ and from 0.013 to $0.212 \mathrm{mg} \mathrm{mL}^{-1}$ for simvastatin and $\mathrm{AgNP}_{\text {bio }}$, respectively. Previously grown bacteria were suspended in saline according to $0.5 \mathrm{McF}$ arland. This bacterial suspension was diluted in MHB to a ratio of 1:100 and inoculated in 96well microplates at a density of $5.0 \times 10^{5} \mathrm{CFU} \mathrm{mL}^{-1}$ per well. 
After 24 hrs of incubation at $37^{\circ} \mathrm{C}$, the checkerboard was read visually and defined as minimal concentration that inhibits bacterial growth visually according to turbidity. The assay was performed in triplicate.

To qualify the interaction between both compounds, we calculated the fractional inhibitory concentration index (FICI) as previously described, ${ }^{39}$ using MIC combined of both compounds (MICc) and MIC alone of each compounds (MICa) the following equation:

$$
\mathrm{FICI}=\frac{\mathrm{MICc}_{\text {simv }}}{\mathrm{MICa}_{\text {simv }}}+\frac{\mathrm{MICc}_{\mathrm{AgNP}}}{\mathrm{MICa}_{\mathrm{AgNP}}}
$$

We interpreted FICI according to the following index: $\leq 0.5$, synergistic interaction effect; $>0.5$ and $\leq 1.0$, additive interaction effect; $>1$ and $<4$, indifferent; and $\geq 4$, antagonistic interaction effect.

\section{Time-Kill Curve Assay}

Time-kill curves were determined according to the National Committee for Clinical Laboratory Standards ${ }^{40}$ to evaluate the effect of simvastatin and $\mathrm{AgNP}_{\text {bio }}$ on growth kinetics of MRSA N315 and E. coli ESBL 176 producing. Bacterial strains were grown previously, and we prepared an inoculum corresponding to 0.5 on the McFarland scale and diluted in MHB to a ratio of 1:100. The compounds were tested alone and in combination, according to MIC and checkerboard assay, respectively, and compared with the bacterial positive control. At different time points of treatment and incubation $(0,2,4,7,10$, and $24 \mathrm{hrs})$ aliquots of bacterial culture were diluted and transferred to a plate with MHA to quantify the number of viable cells. After incubation of the MHA plate at $37^{\circ} \mathrm{C}$ for $24 \mathrm{hrs}$, CFUs were counted and a time-kill curve was constructed. The assay was performed in triplicate.

\section{Cytotoxicity Assay In Human Red Blood Cells}

Hemolytic assay of $\mathrm{AgNP}_{\text {bio }}$ and simvastatin was performed as Izumi et al $2012^{41}$ with modifications. Human red blood cells (HRBC) were taken from a healthy donor and approved by the human ethics committee (CAAE 47661115.0.0000.5231, No. 1.268.019 - UEL). HRBC were collected in heparinized tubes (vacutainer), separated by centrifugation $\left(5000 \mathrm{rpm}, 4^{\circ} \mathrm{C}, 5 \mathrm{mins}\right)$ and diluted in $6 \% \mathrm{v} \mathrm{v}^{-1}$ of phosphate-buffered saline $(0.1 \mathrm{M}$ PBS, $\mathrm{pH}$ 7,2). In a 96 -well plate, $100 \mu \mathrm{L}$ of HRBC $6 \%$ was added in $100 \mu \mathrm{L}$ of $\mathrm{AgNP}_{\text {bio }}$ and simvastatin alone.

After $3 \mathrm{hrs}$ of incubation at $37^{\circ} \mathrm{C}$, the supernatant was removed and read $550 \mathrm{~nm}$. Triton-X 100 1\% (Sigma-Aldrich) was used as a positive control for hemolysis. Concentration range tested was 0.015 .6 to $0.125 \mathrm{mg} \mathrm{mL}^{-1}$ simvastatin and to $\mathrm{AgNP}_{\text {bio }}$ was 0.013 to $0.212 \mathrm{mg} \mathrm{mL}^{-1}$. Cytotoxic concentration in $50 \%\left(\mathrm{CC}_{50}\right)$ of $\mathrm{HRBC}$ was calculated for each compound through linear regression. Selectivity index (SI) was determined using following equation: $\mathrm{SI}=\mathrm{CC}_{50} / \mathrm{IC}_{50}$.

\section{Scanning Electron Microscopy (SEM)}

The MRSA N315 strain exposed to 4 situations was analyzed by SEM, as follows: (1) bacteria without antimicrobial treatment (control), (2) bacteria treated with $0.500 \mathrm{mg} \mathrm{mL}^{-1}$ of simvastatin, (3) bacteria treated with $\mathrm{AgNP}_{\text {bio }}$ at 0.212 $\mathrm{mg} \mathrm{mL} \mathrm{m}^{-1}$, and (4) bacteria exposed to a combination of $0.125 \mathrm{mg} \mathrm{mL}^{-1}$ of simvastatin and $\mathrm{AgNP}_{\text {bio }}$ at $0.106 \mathrm{mg} \mathrm{mL}^{-1}$ respectively. Previously grown MRSA $\mathrm{N} 315$ strains were suspended according to $0.5 \mathrm{McF}$ arland turbidity. A suspension containing approximately $10^{8} \mathrm{CFU}$ $\mathrm{mL}^{-1}$ was prepared in MHB and all 4 samples were incubated at $37^{\circ} \mathrm{C}$ for $3 \mathrm{hrs}$. Next, the bacterial cells were obtained by centrifugation $\left(5310 \times \mathrm{g}\right.$, for $5 \mathrm{mins}$ at $\left.10^{\circ} \mathrm{C}\right)$ and washed and suspended with $0.1 \mathrm{M}$ phosphate-buffered saline (PBS) at $\mathrm{pH}$ 7.4. $20 \mu \mathrm{L}$ cell suspensions of MRSA N315 were spotted on glass slides previously coated with a thin layer of $10 \%$ poly-L-lysine. Afterwards, we fixed each slide containing MRSA N315 through immersion in $1 \mathrm{~mL}$ of $2 \%$ glutaraldehyde and $2 \%$ paraformaldehyde in $0.1 \mathrm{M}$ sodium cacodylate buffer ( $\mathrm{pH}$ 7.2) solution for $12 \mathrm{hrs,} \mathrm{fol-}$ lowed by post-fixation in $1 \% \mathrm{OsO}_{4}$ for $2 \mathrm{hrs}$.

Subsequently, the samples were dehydrated in graded ethanol series (70, 80, 90, and $100 \mathrm{GL})$ and critical point dried using $\mathrm{CO}_{2}$ (BALTEC CPD 030 Critical Point Dryer). The slides were taped onto stubs, coated with gold (BALTEC SDC 050 Sputter Coater), and finally examined using a FEI Quanta 200 scanning electron microscope. ${ }^{42}$

\section{Statistical Methods}

We evaluated the results by two-way ANOVA and standard deviation using $\mathrm{R}$ cran and considering $\mathrm{p}<0.05$ significant. All samples were made in triplicate. Linear regression was performed to determine $\mathrm{CC}_{50}$ of cytotoxic assay.

\section{Results}

\section{Characterization Of The $\mathrm{AgNP}_{\text {bio }}$ And Simvastatin}

The average $\mathrm{AgNP}_{\text {bio }}$ size was $77.68 \pm 33.95 \mathrm{~nm}$ and average zeta potential was $-34.6 \pm 12.7 \mathrm{mV}$ (Supplementary data). PDI for $\mathrm{AgNP}_{\text {bio }}$ was 0.182. TEM images show 


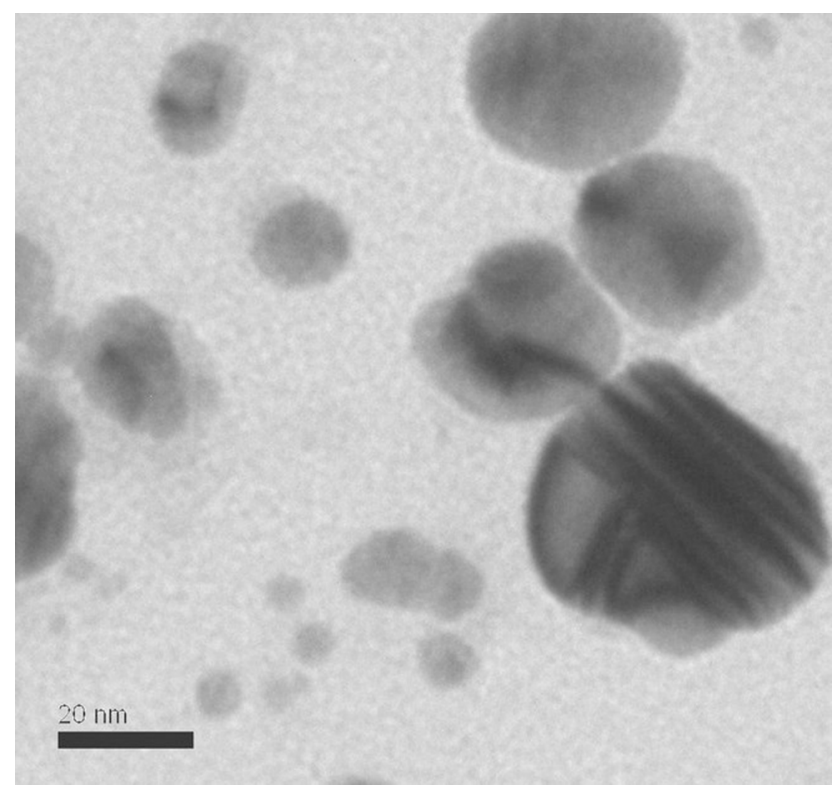

Figure I Characterization by transmission electron microscopy (TEM) of $\mathrm{AgNP}_{\text {bio }}$ synthesized by Fusarium oxysporum (300,000x).

$\mathrm{AgNP}_{\text {bio }}$ average size of 50nm (Figure 1). Particle size of simvastatin was $110.8 \pm 46.8 \mathrm{~nm}$. UV-Vis wavelength corresponding to $\mathrm{AgNP}_{\text {bio }}$ was $420 \mathrm{~nm}^{22}$ (Figure 2).

\section{Antimicrobial Disk Susceptibility Test - Disk Diffusion}

The antimicrobial disk susceptibility assay showed that $\mathrm{AgNP}_{\text {bio }}$ formed inhibition zones against MSSA ATCC 25923, E. coli ATCC 25922, and multidrug-resistant strains. The disk containing simvastatin showed no inhibition of either Gram-positive or Gram-negative bacteria, not forming inhibition zones (Table 1).

\section{Minimal Inhibitory Concentration Of Simvastatin And AgNP}

Simvastatin only demonstrated antibacterial activity against the Gram-positive bacterial strains MSSA ATCC 25923, MSSA ATCC 29213, MRSA BEC 9393, and MRSA $\mathrm{N} 315$, with MIC values ranging from $0.062 \mathrm{mg} \mathrm{mL}^{-1}$ to $0.25 \mathrm{mg} \mathrm{mL}^{-1}$. $\mathrm{AgNP}_{\text {bio }}$ showed a broad spectrum of action, acting against Gram-positive and Gram-negative bacterial strains, with an MIC value of $0.212 \mathrm{mg} \mathrm{mL}^{-1}$ against MSSA ATCC 25923, MSSA ATCC 29213, MRSA N315, and MRSA BEC 9393, and $0.106 \mathrm{mg} \mathrm{mL}^{-1}$ against $E$. coli ATCC 25922 and E. coli ESBL 176 producing (Table 1). Simvastatin and $\mathrm{AgNP}_{\text {bio }}$ presented MICs of $0.062 \mathrm{mg} \mathrm{mL}^{-1}$ and $0.212 \mathrm{mg} \mathrm{mL}^{-1}$, respectively, against MRSA N315. E. coli ESBL 176 demonstrated no susceptibility to simvastatin, whereas $\mathrm{AgNP}_{\text {bio }}$ was active against this strain at an MIC value of $0.106 \mathrm{mg} \mathrm{mL}^{-1}$. DMSO control not inhibited bacterial growth.

\section{Antibacterial Combination Assay (Checkerboard)}

The results of the checkerboard assay (Table 1) showed that there were synergistic and additive antibacterial effects between simvastatin and $\mathrm{AgNP}_{\text {bio. }}$. The combination demonstrated potentiated antibacterial activity against MRSA N315 and MSSA ATCC 25923, decreasing the concentration used for antibacterial effect. The concentration was

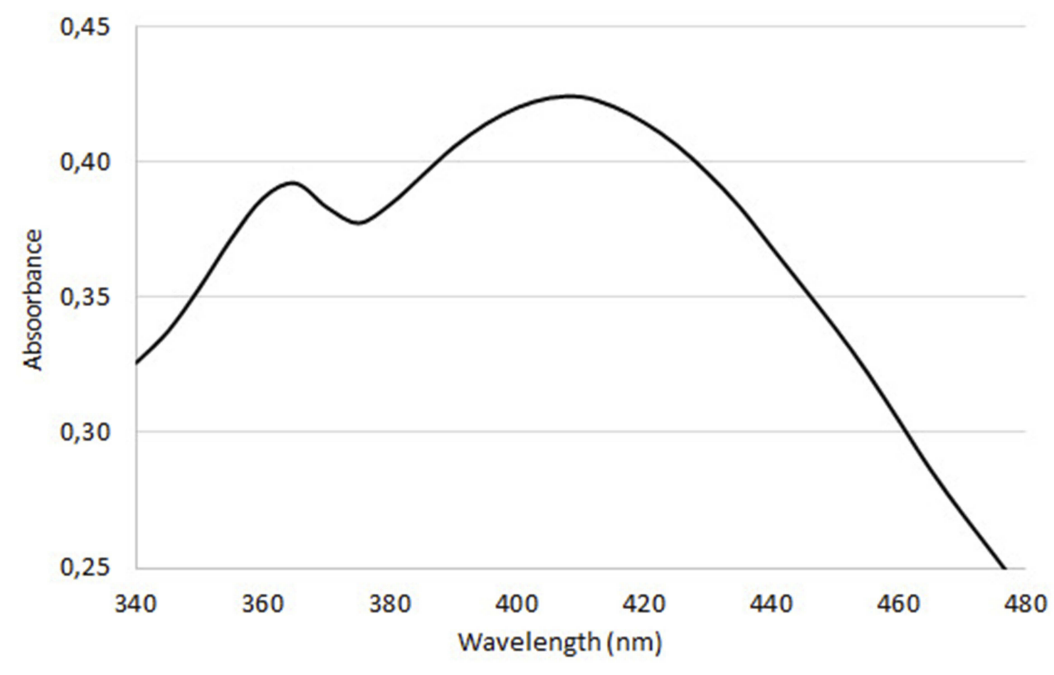

Figure 2 UV-Vis spectrophotometry of nanoparticles synthetized by Fusarium oxysporum. 
Table I Results Of Antimicrobial Disk Susceptibility And Minimal Inhibitory Concentration (MIC), Checkerboard, And Fractional Inhibitory Concentration (FICl) For Bacterial Strains

\begin{tabular}{|c|c|c|c|c|c|c|}
\hline \multirow[t]{2}{*}{ Bacterial strain } & \multicolumn{2}{|c|}{$\begin{array}{l}\text { Inhibition Zone Size } \\
(\mathrm{mm})\end{array}$} & \multicolumn{2}{|c|}{$\begin{array}{l}\text { Minimal Inhibitory } \\
\text { Concentration (MIC) }\end{array}$} & \multicolumn{2}{|c|}{$\begin{array}{l}\text { MIC Of Simvastatin And AgNP }{ }_{\text {bio }} \text { Combined } \\
\left(\mathrm{mg} \mathrm{mL}^{-1} ; \mathrm{mg} \mathrm{mL}^{-1}\right)\end{array}$} \\
\hline & Sim & $\mathbf{A g N P}_{\text {bio }}$ & Sim & $\mathbf{A g N P}_{\text {bio }}$ & Comb & $\mathbf{F I C l}$ \\
\hline MSSA ATCC 25923 & 0 & 7.33 & 0.062 & 0.212 & $0.015 ; 0.052$ & $0.5(S)$ \\
\hline MSSA ATCC 29213 & 0 & 7.75 & 0.062 & 0.212 & $0.031 ; 0.052$ & $0.75(\mathrm{~A})$ \\
\hline MRSA N3I5 & 0 & 7.33 & 0.062 & 0.212 & $0.015 ; 0.052$ & $0.5(\mathrm{~S})$ \\
\hline MRSA BEC 9393 & 0 & 8 & 0.250 & 0.212 & $0.031 ; 0.106$ & $0.62(\mathrm{~A})$ \\
\hline Escherichia coli ESBL I76 & 0 & 9.33 & $>0.250$ & 0.106 & $0.015 ; 0.052$ & $*$ \\
\hline E. coli ATCC 25922 & 0 & 8.33 & $>0.250$ & 0.106 & $0.062 ; 0.106$ & $*$ \\
\hline
\end{tabular}

Notes: MIC: minimal inhibitory concentration; $\mathrm{FICl}$ : fractional inhibitory concentration index was calculated as previously described ${ }^{36}$ and we interpreted it as follows: $\mathrm{FICl}$ $\leq 0.5$, synergistic interaction effect; $>0.5-1.0$, additive interaction effect; $>$ I and $<4$, indifferent; $\geq 4$, antagonistic interaction effect. SIM: simvastatin; $A g N P_{\text {bio: }}$ silver nanoparticles obtained by Fusarium oxysporum, Comb: combination of simvastatin and $\mathrm{AgNP}_{\text {bio. }}$ Methicillin-resistant Staphylococcus aureus (MRSA); Methicillin-sensitive Staphylococcus aureus (MSSA); American Types Culture Collection (ATCC); Extended-Spectrum Beta-lactamase (ESBL). FICl: (S): synergistic interaction effect; (A): additive interaction effect; *FICl was not calculated.

reduced to $75 \%$ when simvastatin and $\mathrm{AgNP}_{\text {bio }}$ were in combination.

\section{Time-Kill Curve Assay}

The results showed that simvastatin, when used alone, had a bacteriostatic effect against MRSA N315 (Figure 3), while $\mathrm{AgNP}_{\text {bio }}$, at $24 \mathrm{hrs}$, had a bactericidal effect. Combination of $\mathrm{AgNP}_{\text {bio }}$ with simvastatin shows difference between treatments alone of $\operatorname{AgNP}_{\text {bio }}(\mathrm{p}<0.05)$ e simvastatin $(\mathrm{p}<0.05)$ eliminate entire bacterial population.

Afer $10 \mathrm{hrs}$ of incubation, all cells of the bacterial population were eradicated by simvastatin and $\mathrm{AgNP}_{\text {bio }}$ combined ( $\mathrm{p}<0.05$ ), against N315 MRSA. In comparison, simvastatin when used alone against $E$. coli ESBL 176 not showed antibacterial activity (Figure 4). $\operatorname{AgNP}_{\text {bio }}$ was bactericidal in 24 hrs against MRSA N315 and decreased the concentration cells in $4 \mathrm{hrs}$. Simvastatin was bacteriostatic, and the combination was more effective than simvastatin used alone, showing bactericidal activity in $4 \mathrm{hrs}$.

\section{Cytotoxicity Assay In HRBC}

Simvastatin showed a $\mathrm{CC}_{50}$ in $\mathrm{HRBC}$ in range of $0.260 \mathrm{mg} \mathrm{mL}^{-1}$. $\mathrm{CC}_{50} \mathrm{AgNP}_{\text {bio }}$ was $9283.4 \mathrm{mg} \mathrm{mL}^{-1} \cdot \mathrm{CC}_{50}$ of simvastatin and $\mathrm{AgNP}_{\text {bio }}$ was the concentration above MIC $0.260 \mathrm{mg} \mathrm{mL}^{-1}$ and $9.283 .4 \mathrm{mg} \mathrm{mL}^{-1}$, respectively. SI was 4.193 for simvastatin and 43.789 for $\mathrm{AgNP}_{\text {bio. }}$.

\section{Scanning Electron Microscopy (SEM)}

SEM analysis showed that the untreated MRSA N315 sample presented a large number of smooth cells, an intact

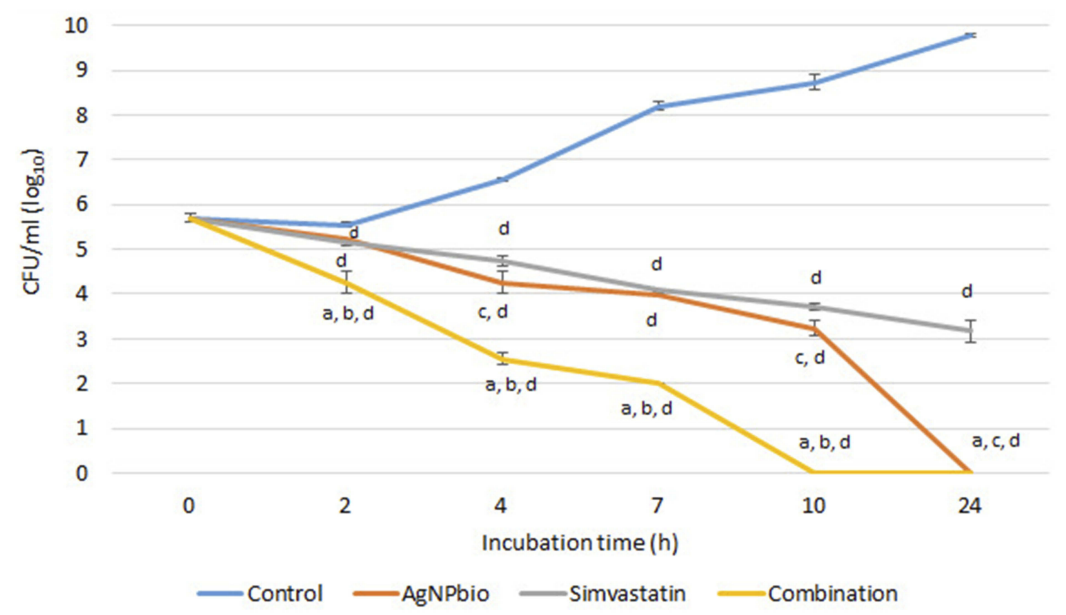

Figure 3 Time-kill curves for methicillin-resistant Staphylococcus aureus N3I5. AgNP bio treatment at a concentration of $212.33 \mathrm{mg} \mathrm{mL}^{-1}$; treatment with $0.062 \mathrm{mg} \mathrm{mL}^{-1}$

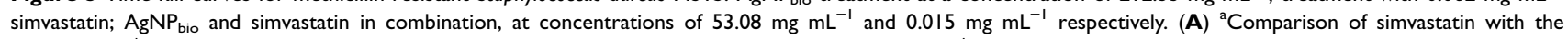
combination; ${ }^{b}$ comparison of $\mathrm{AgNP}_{\text {bio }}$ with the combination; ${ }^{c}$ comparison of simvastatin with $\mathrm{AgNP}_{\text {bio; }}$; treatments compared to control. 


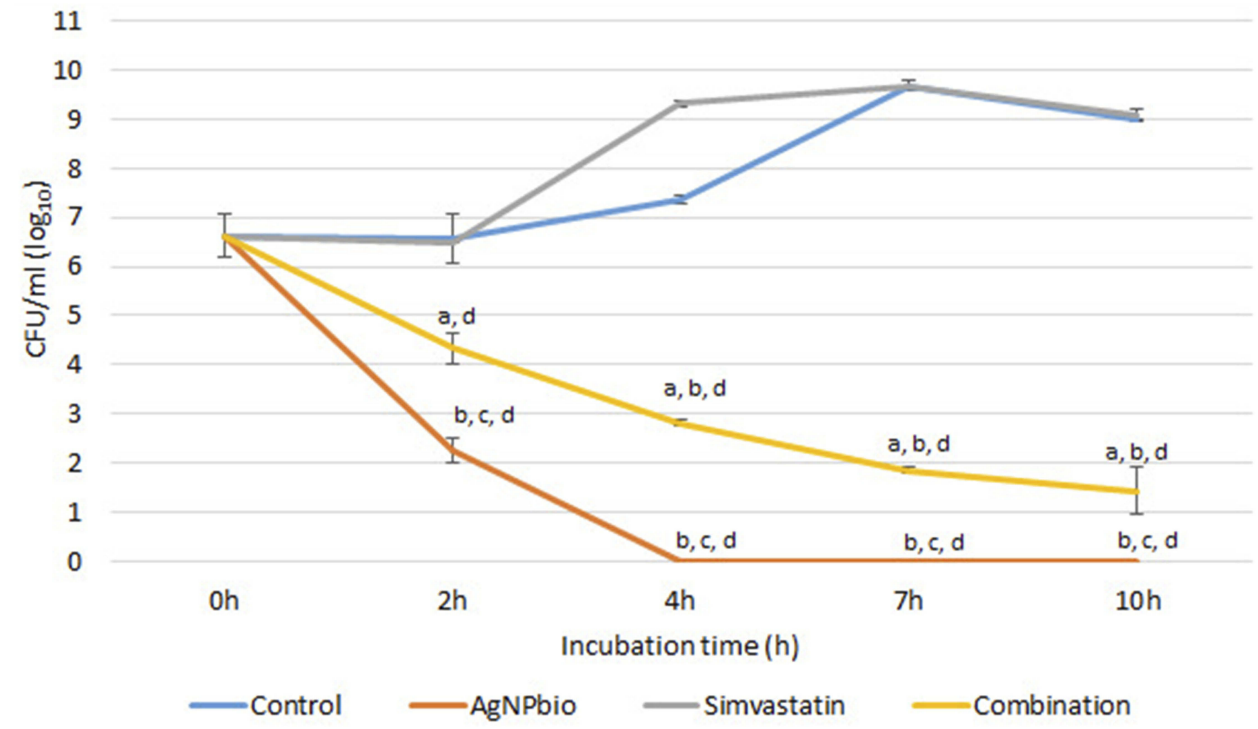

Figure 4 Time-kill curves for extended-spectrum beta lactamases-producing Escherichia coli $176 . \mathrm{AgNP}_{\text {bio }}$ treatment at a concentration of $2 \mathrm{I} 2.33 \mathrm{mg} \mathrm{mL}^{-1}$; treatment with

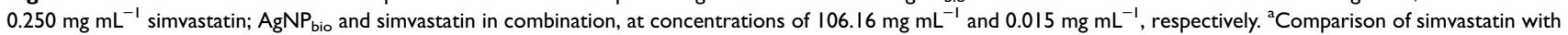
the combination; ${ }^{\mathrm{b}}$ comparison of $\mathrm{AgNP}_{\text {bio }}$ with the combination; ${ }^{\mathrm{c}}$ comparison of simvastatin with $\mathrm{AgNP}_{\text {bio; }}{ }^{\mathrm{d}}$ treatments compared to control.

surface, and unaltered average size, with typical features unchanged in format, arrangement, and appearance as found in treated cells (Figure 5A and B). The MRSA N315 sample exposed to simvastatin treatment presented some cells with normal appearance, arrangement, and format, while others presented deformations; the micrographs demonstrated the formation of a large amorphous mass caused by destruction of the bacterial cells in the treatment with simvastatin (Figure $5 \mathrm{C}$ and $\mathrm{D}$ ). The $\mathrm{AgNP}_{\text {bio }}$ treatment caused alterations in cell morphology, such as protrusions of numerous small bubbles a few nanometers in size; the metal nanoparticles also resulted in numerous lysed cells and cell debris (Figure 5E and F). Cells treated with a combination of simvastatin and $\mathrm{AgNP}_{\text {bio }}$ showed
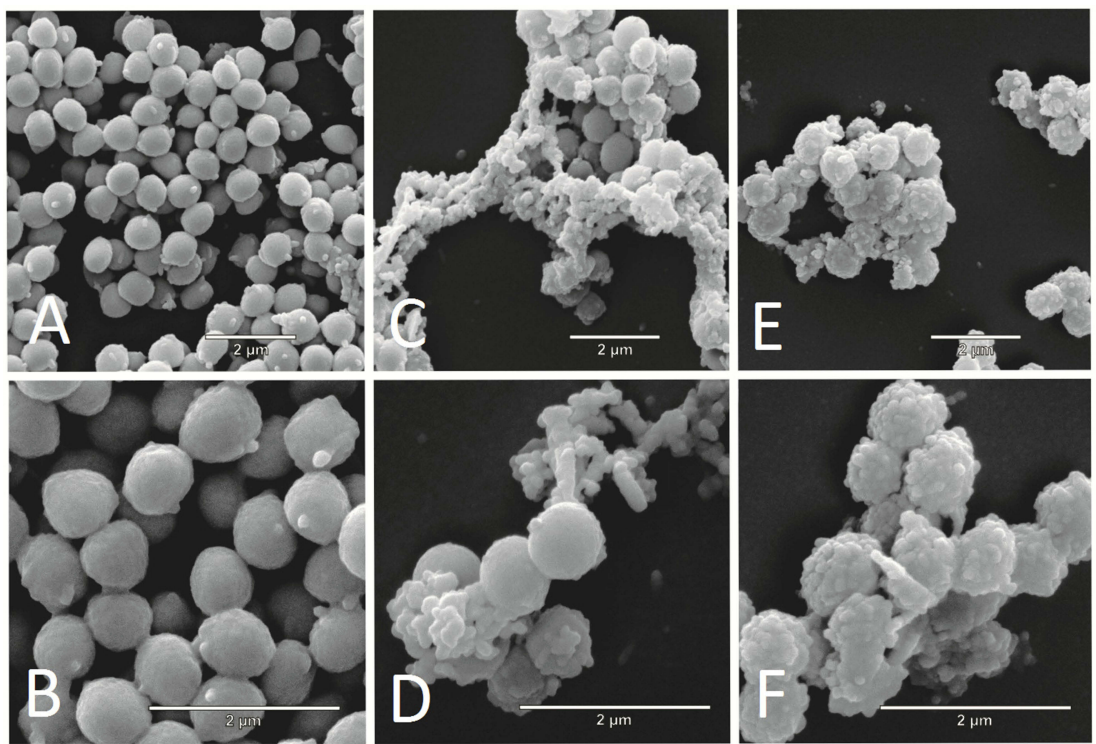
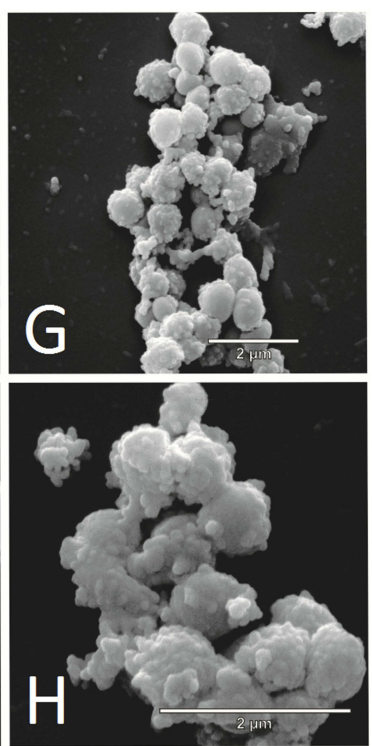

Figure 5 Scanning electron microscopy (SEM) images of methicillin-resistant Staphylococcus aureus (MRSA) N3I5 after 3 hrs of incubation. (A) Negative control (not treated) $(25,000 \times)$. (B) Positive control $(50,000 \times)$. (C) Treatment with $0.050 \mathrm{mg} \mathrm{mL}^{-1}$ simvastatin $(25,000 \times)$. (D) Treatment with $0.050 \mathrm{mg} \mathrm{mL}$ of simvastatin (50,000×). (E) Treatment with $212.33 \mathrm{mg} \mathrm{mL}^{-1}$ of $\mathrm{AgNP}_{\text {bio }}(25,000 \times)$. (F) Treatment with $212.33 \mathrm{mg} \mathrm{mL}^{-1}$ of $\mathrm{AgNP}_{\text {bio }}(50,000 \times)$. (G) Treatment with $0.012 \mathrm{mg} \mathrm{mL}^{-1}$ of simvastatin and $106.16 \mathrm{mg} \mathrm{mL}^{-1}$ of $\mathrm{AgNP}_{\text {bio }}$ in combination $(25,000 \times)$. (H) Treatment with $0.012 \mathrm{mg} \mathrm{mL}^{-1}$ of simvastatin and 106.16 mg.mL of AgNP bio in combination $(50,000 \times)$. 
both types of alterations: formation of a large amorphous mass caused by simvastatin and a protrusion of numerous small bubbles caused by $\mathrm{AgNP}_{\text {bio. }}$ It was possible to identify cell surface protrusions, amorphous mass, small bubbles, lysed cells, and cell debris, showing the interaction between the two compounds (Figure $5 \mathrm{G}$ and $\mathrm{H}$ ).

\section{Discussion}

Statins are used for treatment antihyperlipidemic effects in patients with high cholesterol by competitively inhibiting the enzyme HMG-CoA reductase, decreasing cholesterol biosynthesis. ${ }^{5}$ Simvastatin is also known to present pleiotropic effects, such as anti-inflammatory, antithrombotic, and antimicrobial effect. ${ }^{6-8}$ and shows hepatocyte cytotoxicity. ${ }^{43}$ Therefore, the combination and consequent decrease in the concentrations of simvastatin have advantages in reducing cytotoxicity.

Results obtained by disk diffusion assay showed no inhibition by simvastatin in any bacteria tested. Antibacterial activity was demonstrated by broth microdilution assay, showing an inhibitory effect of simvastatin against MSSA and MRSA strains. Several studies have performed only disk or well diffusion into agar for evaluation of antimicrobial activity, mainly assay with nanoparticles, but some compounds do not diffuse into agar very well, other methods being recommended such as microdilution in broth and timekill curves. $^{22}$ Our results showed small halos (inhibition zones) for $\mathrm{AgNP}_{\text {bio }}$ and none for simvastatin, but high antibacterial activity in the broth microdilution and time-kill curves. This method can be performed as screening assay and other techniques are recommended for complete evaluation for antibacterial activity.

Several studies have shown that simvastatin has an antibacterial effect against $S$. aureus strains, with $\mathrm{MIC}$ ranging from $0.050 \mathrm{mg} \mathrm{mL}^{-1}$ to $0.300 \mathrm{mg} \mathrm{mL}^{-1.8,44-46}$ Results obtained in the literature show that MIC values are similar to those obtained in our study. In general, MIC values are higher in MRSA than MSSA, although this was not observed in our study. The results obtained for simvastatin against $E$. coli (ESBL 176 and ATCC 25922) demonstrated no antibacterial effect. A recent study obtained the same results: simvastatin showed no antibacterial effect against Gram-negative bacteria. ${ }^{47}$ Structural differences between Gram-positive and Gram-negative bacteria could lead to the difference in the antibacterial activity of simvastatin. According to a previous study, statins have a bacteriostatic effect against $S$. aureus strains, ${ }^{46}$ and similar results were obtained in the present study, where simvastatin showed growth inhibition of the MRSA tested.

Our results demonstrated an inhibitory effect of $\mathrm{AgNP}_{\text {bio }}$ against $S$. aureus and E. coli. The broad spectrum of antibacterial activity of $\mathrm{AgNP}_{\text {bio }}$ could be due to different targets in bacteria cells such as DNA, vital enzymes, and cell membrane, structures present in both Gram-positive and Gram-negative bacteria. ${ }^{16}$ The same inhibitory effects against $S$. aureus and $E$. coli were reported in earlier studies. ${ }^{48,49}$ Our silver nanoparticles are biogenic (by $F$. oxysporum) with an average diameter of $77.68 \pm$ $33.95 \mathrm{~nm}$. AgNP bio $\mathrm{MIC}$ values were $212.33 \mathrm{mg} \mathrm{mL}^{-1}$ for $S$. aureus and $106.16 \mathrm{mg} \mathrm{mL}^{-1}$ for $E$. coli strains, keeping the same MIC for more than one year (data not shown). MIC value was lower for $E$. coli than $S$. aureus strains, showing that the antibacterial effect of $\mathrm{AgNP}_{\text {bio }}$ was higher for $E$. coli strains (Gram-negative). Gram-positive and Gram-negative bacteria present differences in structure such as peptidoglycan (cell wall) and this difference may interfere in antibacterial activity in Gram-positive bacteria (peptidoglycan thicker). Other factors that influence the antibacterial activity of $\mathrm{AgNP}_{\text {bio }}$ are size, morphology, and coating of nanoparticles. $\mathrm{AgNP}_{\text {bio }}$ with smaller sizes are more efficient than nanoparticles of larger size. $^{16,50,51}$

Resistance to antimicrobials reduces the range of treatment options by increasing the cost and making it more difficult to eliminate microorganisms through enhanced severity of infections. ${ }^{1}$ Therefore, there is a necessity to discover new treatment options. Studies have recommended the combination of drugs as a strategy to control antimicrobial resistance. ${ }^{52,53}$ Studies involving synergism have been especially important for multidrug-resistant bacteria therapy. $^{17,31}$ Therefore, there is a need to search for new antibiotics. Regarding the search for new treatments, in addition to the investigation of new drugs, combinations with AgNP and another compound such as amoxicillin, ${ }^{18}$ cinnamaldehyde, ${ }^{32}$ eugenol, ${ }^{31}$ oregano essential oil, ${ }^{14}$ and phenazine-1-carboxamide ${ }^{12}$ have demonstrated better antibacterial action when combined. Simvastatin when combined with $\mathrm{AgNP}_{\text {bio }}$ presents a new treatment option against infections caused mainly by $S$. aureus and E. coli. Our results showed that simvastatin when used alone has a bacteriostatic effect, not being as effective against bacteria. Although $\mathrm{AgNP}_{\text {bio }}$ has a bactericidal effect when used alone, bacterial resistance has been described. ${ }^{28}$ The use of the combination, in addition to improving activity, decreases the time of action and concentration, and minimizes the 
occurrence of resistance (lower dose). This combination has a greater effect than isolated drugs, establishing a new perspective for treating infections.

A recent study shows antifungal activity of the simvastatin combined with $\mathrm{AgNP}_{\text {bio }}$ synthetized by F. oxysporum against species of Aspergillus. ${ }^{33}$ This study reported, for the first time, combination of statins and nanoparticles against bacteria including multidrug-resistant bacteria strains. In the checkerboard test, the combination of simvastatin and $\mathrm{AgNP}_{\text {bio }}$ showed a synergistic effect against MSSA ATCC 25923 and MRSA N315, demonstrating that the combination decreased to $75 \%$ the concentration used to eliminate these bacteria. In addition, the combination of both compounds against MRSA BEC 9393 and MSSA ATCC 29213 presented an additive antibacterial effect, decreasing by $50 \%$ the concentration to eliminate these bacteria. Our results showed that simvastatin used in combination with $\mathrm{AgNP}_{\text {bio }}$ caused a 2-log decrease in the bacterial population at $4 \mathrm{hrs}$ when used against MRSA. The MIC values decreased 4-fold for both, indicating a synergistic effect between the two compounds. When the combination was used, all bacteria were eliminated within $10 \mathrm{hrs}$, which was less than half the time observed for separate applications.

Studies have used $\mathrm{AgNP}_{\text {bio }}$ with other compounds, showing a synergistic interaction effect. The combination of $\mathrm{AgNP}_{\text {bio }}$ with phenazine-1-carboxylic caused a decrease in MIC. ${ }^{12} \mathrm{AgNP}_{\text {bio }}$ in combination with eugenol showed a synergistic interaction effect against $S$. agalactiae. $^{31}$ $\mathrm{AgNP}_{\text {bio }}$ combined with oregano essential oil demonstrated a synergistic and additive effect against multidrug-resistant bacterial strains. ${ }^{14}$ Simvastatin, when combined with $\mathrm{AgNP}_{\text {bio, }}$, showed a synergistic effect against some strains of $S$. aureus, including MRSA. The synergic effect of the simvastatin with $\mathrm{AgNP}_{\text {bio }}$ decreased the inhibitory concentration to 4-fold for both compounds, also therapeutic concentration.

Another important aspect of this synergism is the toxicity of simvastatin and $\mathrm{AgNP}_{\text {bio. }}$. Simvastatin has presented hepatotoxicity in humans. ${ }^{54}$ In relation to $\mathrm{AgNP}_{\text {bio }}$, there is also concern with the environment. Thus, our results showed that low concentrations of both compounds had a higher effect than alone (synergism). ${ }^{22}$ In HRBC cells, simvastatin shows a $\mathrm{CC}_{50}$ in concentration of $0.260 \mathrm{mg} \mathrm{mL}^{-1}$ and $\mathrm{AgNP}_{\text {bio }}$ $\mathrm{CC}_{50}$ of $9283.4 \mathrm{mg} \mathrm{mL}^{-1}$. Results of SI showed viable application in medical area.

There are no reports of SEM in the literature of bacteria treated with simvastatin. Our results showed morphological alteration in the bacterial cells similar to an amorphous mass. Through SEM, we observed cellular morphological alterations within a few hours of incubation with treatments of simvastatin, $\mathrm{AgNP}_{\mathrm{bio}}$, and a combination of both compounds. A previous study obtained images of samples treated with $\mathrm{AgNP}_{\text {bio }}$ showing a formation of protrusions on the surface of most cells. Studies have demonstrated that the cytoplasmic material is lost, suggesting that $\mathrm{AgNP}_{\text {bio }}$ interferes with the permeability of the bacterial cell membrane. ${ }^{14,31,55}$ In our study, treatment with $\mathrm{AgNP}_{\text {bio }}$ caused the formation of protrusions of numerous small bubbles a few nanometers in size, numerous lysed cells, and cell debris, suggesting the similar mechanism of action. In SEM, the combination of $\mathrm{AgNP}_{\text {bio }}$ and simvastatin showed cellular morphological alterations characteristic of both compounds. Studies using the combination of $\mathrm{AgNP}_{\text {bio }}$ and other compounds obtained similar results. ${ }^{14,31}$

\section{Conclusion}

In conclusion, our study showed synergism interactions effect between simvastatin and $\mathrm{AgNP}_{\text {bio }}$ synthetized by $F$. oxysporum, on antibacterial activity against a MRSA N315. These data suggest that the combination of these compounds is a possible treatment option for fighting resistant bacterial infections. In addition, it was possible to observe different cell changes under simvastatin and $\mathrm{AgNP}_{\text {bio }}$ by SEM.

The combination of simvastatin and $\mathrm{AgNP}_{\text {bio }}$ has potential to be applied in industry (pharmaceutical) and hospitals (impregnated in materials and treatment of wounds and burns infections).

Mechanism of action and physical-chemical compatibility of the combination of compounds are the next steps of our group.

\section{Acknowledgments}

This study was supported by CNPq BIOTEC 402728/ 2013-0 and CAPES, which made this study possible. Support from INOMAT (MCTI/CNPq), NanoBioss (MCTI), and the Brazilian Network of Nanotoxicology (MCTI/CNPq) is also acknowledged. The authors would also like to thank the Laboratory for Electron Microscopy and Microanalysis - LMEM/Universidade Estadual de Londrina and Central de Microscopia - COMCAP/ Universidade Estadual de Maringá for help with the electron microscopy experiments. We thank Dr. Elsa Masae and Dr. Agnes Marie Sá Figueiredo who donated the 
MRSA N315 and MRSA BEC9393 strains. Dr. A. Leyva helped with English editing of the manuscript.

\section{Disclosure}

The authors report no conflicts of interest in this work.

\section{References}

1. O'Neill J. Tackling drug-resistant infections globally: final report and recommendations. Rev Antimicrob Resist. 2016;1-80.

2. Cantas L, Shah SQA, Cavaco LM, et al. A brief multi-disciplinary review on antimicrobial resistance in medicine and its linkage to the global environmental microbiota. Front Microbiol. 2013;4:1-14. doi:10.3389/fmicb.2013.00077

3. Silva KC, Lincopan N. Epidemiologia das betalactamases de espectro estendido no Brasil: impacto clínico e implicações para o agronegócio. J Bras Patol E Med Lab. 2012;48(2):91-99. doi:10.1590/S1676-24442012000200004

4. Bodnar GC, Martins HM, De Oliveira CF, et al. Comparison of HRM analysis and three REP-PCR genomic fingerprint methods for rapid typing of MRSA at a Brazilian hospital. J Infect Dev Ctries. 2016;10 (12):1306-1317. doi:10.3855/jidc.7887

5. Graziano TS, Cuzzullin MC, Franco GC, et al. Statins and antimicrobial effects: simvastatin as a potential drug against Staphylococcus aureus biofilm. PLoS One. 2015;10(5):1-17. doi:10.1371/journal. pone. 0128098

6. Friesen JA, Rodwell VW. The 3-hydroxy-3-methylglutaryl coenzyme-A (HMG-CoA) reductases. Genome Biol. 2004;5(11):248. doi:10.1186/gb-2004-5-11-248

7. Jain MK, Ridker PM. Anti-inflammatory effects of statins: clinical evidence and basic mechanisms. Nat Rev Drug Discov. 2005;4 (12):977-987. doi:10.1038/nrd1876

8. Jerwood S, Cohen J. Unexpected antimicrobial effect of statins. J Antimicrob Chemother. 2008;61(2):362-364. doi:10.1093/jac/ dkm496

9. Chen X, Schluesener HJ. Nanosilver: a nanoproduct in medical application. Toxicol Lett. 2008;176(1):1-12. doi:10.1016/j.toxlet.20 07.10.004

10. Ansari MA, Khan HM, Khan AA, Cameotra SS, Saquib Q, Musarrat J. Gum arabic capped-silver nanoparticles inhibit biofilm formation by multi-drug resistant strains of Pseudomonas aeruginosa. J Basic Microbiol. 2014;54(7):688-699. doi:10.1002/jobm.v54.7

11. Bibbs RK, Harris RD, Peoples VA, et al. Silver polyvinyl pyrrolidone nanoparticles exhibit a capsular polysaccharide influenced bactericidal effect against Streptococcus pneumoniae. Front Microbiol. 2014;5:1-8. doi:10.3389/fmicb.2014.00547

12. Cardozo VF, Oliveira AG, Nishio EK, et al. Antibacterial activity of extracellular compounds produced by a Pseudomonas strain against methicillin-resistant Staphylococcus aureus (MRSA) strains. Ann Clin Microbiol Antimicrob. 2013;12:12. doi:10.1186/1476-071112-12

13. Palanisamy NK, Ferina N, Amirulhusni AN, et al. Antibiofilm properties of chemically synthesized silver nanoparticles found against Pseudomonas aeruginosa. J Nanobiotechnology. 2014;12:2. doi:10.1186/1477-3155-12-2

14. Scandorieiro S, De Camargo LC, Lancheros CAC, et al. Synergistic and additive effect of oregano essential oil and biological silver nanoparticles against multidrug-resistant bacterial strains. Front Microbiol. 2016;7. doi:10.3389/fmicb.2016.00760

15. Singh K, Panghal M, Kadyan S, Chaudhary U, Yadav J. Green silver nanoparticles of Phyllanthus amarus: as an antibacterial agent against multi drug resistant clinical isolates of Pseudomonas aeruginosa. J Nanobiotechnology. 2014;12(1):40. doi:10.1186/s12951-014-0040-x.
16. Morones JR, Elechiguerra JL, Camacho A, et al. The bactericidal effect of silver nanoparticles. Nanotechnology. 2005;16(10):23462353. doi:10.1088/0957-4484/16/10/059

17. Lok C, Ho C, Chen R, et al. Proteomic analysis of the mode of antibacterial action of silver. J Proteome Res. 2006;5:916-924. doi:10.1021/pr0504079

18. Li P, Li J, Wu C, Wu Q, Li J. Synergistic antibacterial effects of $\beta$-lactam antibiotic combined with silver nanoparticles. Nanotechnology. 2005;16 (9):1912-1917. doi:10.1088/0957-4484/16/9/082

19. Durán N, Durán M, de Jesus MB, Seabra AB, Fávaro WJ, Nakazato G. Silver nanoparticles: a new view on mechanistic aspects on antimicrobial activity. Nanomedicine. 2015;12(3):789-799. doi:10.1016/ j.nano.2015.11.016.

20. Herman A, Herman AP. Nanoparticles as antimicrobial agents: their toxicity and mechanisms of action. J Nanosci Nanotechnol. 2014;14 (1):946-957. doi:10.1166/jnn.2014.8735.

21. Seabra A, Durán N. Nanotoxicology of metal oxide nanoparticles. Metals (Basel). 2015;5(2):934-975. doi:10.3390/met5020934

22. Durán N, Nakazato G, Seabra AB. Antimicrobial activity of biogenic silver nanoparticles, and silver chloride nanoparticles: an overview and comments. Appl Microbiol Biotechnol. 2016;100(15):6555-6570. doi:10.1007/s00253-016-7657-7

23. Durán N, Seabra AB. Metallic oxide nanoparticles: state of the art in biogenic syntheses and their mechanisms. Appl Microbiol Biotechnol. 2012;95(2):275-288. doi:10.1007/s00253-012-4118-9

24. Ingale AG, Chaudhari AN. Biogenic synthesis of nanoparticles and potential applications: an eco- friendly approach. J Nanomed Nanotechnol. 2013;04(02). doi:10.4172/2157-7439.1000165

25. Jelenko C. Silver nitrate resistant E. coli: report of case. Ann Surg. 1969;170(2):296-299. doi:10.1097/00000658-196908000-00021

26. Haefeli C, Franklint C, Hardy K, Biogen SA, Acacias R. Plasmiddetermined silver resistance in Pseudomonas stutzeri isolated from a silver mine. J Bacteriol. 1984;158(1):389-392.

27. McHugh GL, Hopkins CC, Moellering RC, Swartz MN. Salmonella typhymurium resistant to silver nitrate, chloramphenicol, and ampicillin. Lancet. 1975;305:235-240.

28. Graves JL, Tajkarimi M, Cunningham Q, et al. Rapid evolution of silver nanoparticle resistance in Escherichia coli. Front Genet. 2015;5:1-13.

29. Fayaz AM, Balaji K, Girilal M, Yadav R, Kalaichelvan PT, Venketesan R. Biogenic synthesis of silver nanoparticles and their synergistic effect with antibiotics: a study against gram-positive and gram-negative bacteria. Nanomedicine. 2010;6(1):103-109. doi:10.10 16/j.nano.2009.04.006

30. Jain J, Arora S, Rajwade JM, Omray P, Khandelwal S, Paknikar KM. Silver nanoparticles in therapeutics: development of an antimicrobial gel formulation for topical use. Mol Pharm. 2009;6(5):1388-1401. doi: $10.1021 / \mathrm{mp} 800174 \mathrm{~g}$

31. Biasi-garbin RP, Otaguiri ES, Morey AT, et al. Effect of eugenol against Streptococcus agalactiae silver nanoparticles. Evid Based Complement Alternat Med. 2015;2015:1-8. doi:10.1155/2015/861497

32. Ghosh IN, Patil SD, Sharma TK, Srivastava SK, Pathania R, Navani NK. Synergistic action of cinnamaldehyde with silver nanoparticles against spore-forming bacteria: a case for judicious use of silver nanoparticles for antibacterial applications. Int $J$ Nanomedicine. 2013;8:4721-4731. doi:10.2147/IJN.S37465

33. Bocate KP, Reis GF, de Souza PC, et al. Antifungal activity of silver nanoparticles and simvastatin against toxigenic species of Aspergillus. Int J Food Microbiol. 2019;291:79-86. doi:10.1016/j. ijfoodmicro.2018.11.012

34. Durán N, Marcato PD, Alves OL, De GIH, Esposito E. Mechanistic aspects of biosynthesis of silver nanoparticles by several Fusarium oxysporum strains. J Nanobiotechnology. 2005;7:1-7.

35. Bauer AW, Kirby MWM, Jherris JC, Turck M. Antibiotic susceptibility testing by a standardized single disk method. Am J Clin Pathol. 1966;45:493-496. doi:10.1093/ajcp/45.6_ts.764 
36. CLSI. M100-S23 Performance Standards for Antimicrobial Susceptibility Testing; Vol 23; 2013.

37. CLSI. Methods for Dilution Antimicrobial Susceptibility Tests for Bacteria that Grow Aerobically. Vol. 32; 2012:69

38. Kelly MT, Matsen JM. Testing parameters of amikacin, with comparisons to other aminoglycoside antibiotics in vitro activity, synergism, and testing parameters of amikacin, with comparisons to other aminoglycoside antibiotics. Antimicrob Agents Chemother. 1976;9 (3):440-447. doi:10.1128/AAC.9.3.440

39. Chin NX, Weitzman I. In vitro activity of fluvastatin, a cholesterollowering agent, and synergy with flucanazole and itraconazole against Candida species and Cryptococcus neoformans. Antimicrob Agents Chemother. 1997;41(4):850-852. doi:10.1128/AAC.41.4.850

40. NCCLS. Methods for Determinating Bactericidal Activity of Antimicrobial Agents: Aproved Guideline. NCCLS, Vol. 19; 1999:50

41. Izumi E, Veiga VF, Pinto AC, Nakamura CV. Terpenes from copaifera demonstrated in vitro antiparasitic and synergic activity. $J$ Med Chem. 2012;55(7):2994-3001. doi:10.1094/PDIS-11-11-0999-PDN

42. Gonçalves A, Oliveira D, Sayuri L, et al. Evaluation of the antibiotic activity of extracellular compounds produced by the Pseudomonas strain against the Xanthomonas citri pv. Citri 306 Strain. Biol Control. 2011;56:125-131. doi:10.1016/j.biocontrol.2010.10.008

43. Abdoli N, Heidari R, Azarmi Y, Eghbal MA. Mechanisms of the statins cytotoxicity in freshly isolated rat hepatocytes. $J$ Biochem Mol Toxicol. 2013;29(4):165-172.

44. Çoban AY, Tekeli HO, Guney AK, Durupinar B. Investigation of the in vitro antibacterial effects of statins. Mikrobiyol Bul. 2010;161-163.

45. Masadeh M, Mhaidat N, Alzoubi K, Al-azzam S, Alnasser Z. Antibacterial activity of statins: a comparative study of Atorvastatin, Simvastatin, and Rosuvastatin. Ann Clin Microbiol Antimicrob. 2012;11:1-5.
46. Wang -C-C, Yang P-W, Yang S-F, Hsieh K-P, Tseng S-P, Lin Y-C. Topical simvastatin promotes healing of Staphylococcus aureus -contaminated cutaneous wounds. Int Wound J. 2015;1-10. doi:10.1111/ iwj. 12431

47. Thangamani S, Mohammad H, Abushahba MFN, et al. Exploring simvastatin, an antihyperlipidemic drug, as a potential topical antibacterial agent. Sci Rep. 2015;5:1-13. doi:10.1038/srep16407

48. Kim JS, Kuk E, Yu N, et al. Antimicrobial effects of silver nanoparticles. Nanomedicine. 2007;3:95-101. doi:10.1016/j. nano.2006.12.001

49. Mirzajani F, Ghassempour A, Aliahmadi A, Esmaeili MA. Antibacterial effect of silver nanoparticles on Staphylococcus aureus. Res Microbiol. 2011;162(5):542-549. doi:10.1016/j.resmic.2011.04.009

50. Panacek A, Kvítek L, Prucek R, et al. Silver colloid nanoparticles: synthesis, characterization, and their antibacterial activity. $J$ Phys Chem. 2006;33:16248-16253. doi:10.1021/jp063826h

51. Pal S, Tak YK, Song JM. Does the antibacterial activity of silver nanoparticles depend on the shape of the nanoparticle? A study of the gram-negative bacterium Escherichia coli. J Biol Chem. 2015;290 (42):1712-1720.

52. Bollenbach T. Antimicrobial interactions: mechanisms and implications for drug discovery and resistance evolution. Curr Opin Microbiol. 2015;27:1-9. doi:10.1016/j.mib.2015.05.008

53. Fischbach MA. Combination therapies for combating antimicrobial resistance. Curr Opin Microbiol. 2011;14(5):519-523. doi:10.1016/j. mib.2011.08.003

54. Stossel TP. The Discovery of Statins. BenchMarks. 2008;903-905.

55. Kim SH, Lee HS, Ryu DS, Choi SJ, Lee DS. Antibacterial activity of silver-nanoparticles against Staphylococcus aureus and Escherichia coli. Korean J Microbiol Biotechnol. 2011;39(1):77-85.
International Journal of Nanomedicine

\section{Publish your work in this journal}

The International Journal of Nanomedicine is an international, peerreviewed journal focusing on the application of nanotechnology in diagnostics, therapeutics, and drug delivery systems throughout the biomedical field. This journal is indexed on PubMed Central, MedLine, CAS, SciSearch ${ }^{\mathbb{R}}$, Current Contents ${ }^{\mathbb{B}} /$ Clinical Medicine,
Journal Citation Reports/Science Edition, EMBase, Scopus and the Elsevier Bibliographic databases. The manuscript management system is completely online and includes a very quick and fair peer-review system, which is all easy to use. Visit http://www.dovepress.com/ testimonials.php to read real quotes from published authors. 